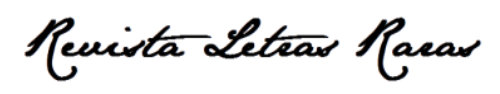

ISSN: 2317-2347 - V. 10, n. 1 (2021)

Todo o conteúdo da RLR está licenciado sob Creative Commons Atribuição 4.0 Internacional

\title{
Intercompreensão: uma prática milenar de troca linguístico- cultural como chave do plurilinguismo
}

\section{Thompson Menezes*}

Bacharel em Direito pela Universidade Católica de Pernambuco, com período sanduíche na Universidad del Salvador (Buenos Aires), sendo especialista em Direito do Trabalho pela Universidade Norte do Paraná. É desde 2019, Mestrando do Programa de Pós-Graduação em Filosofia da Universidade Federal do ABC, no qual realiza pesquisas que envolvem a interface entre filosofia e cinema, confrontando a teórica existencialista Simone de Beauvoir e o cineasta espanhol Pedro Almodóvar. Profissionalmente, atua como Oficial de Justiça Avaliador Federal no Tribunal Regional do Trabalho da $2^{\mathrm{a}}$ Região (São Paulo).

iD https://orcid.org/0000-0001-7489-368X

Recebido em: 27 dez. 2020. Aprovado em: 18 jan. 2021.

\section{Como citar esta resenha:}

Menezes, Thompson. Resenha do livro "Intercompreensão: a chave para as línguas". Revista Letras Raras. Campina Grande, v. 10, n. 1, p. 237-242, jan. 2021.

Resenha da obra:

OLMO, Francisco Calvo Del; ESCUDÉ, Pierre. Intercompreensão: a chave para as línguas. - 1. Ed. - São Paulo: Parabólica, 2019, 224 p.

O livro Intercompreensão: a chave para as línguas, de Francisco Calvo del Olmo (Universidade Federal do Paraná) e Pierre Escudé (Universidade de Bordeaux), é fruto do pósdoutorado daquele sob orientação deste. Ademais, o estudo foi publicado pela editora Parábola, em 2019. Quanto aos pesquisadores, Olmo é líder do grupo de pesquisa em Intercompreensão, Didática do Plurilinguismo e Políticas de Línguas - FLORES, registrado junto à Capes. Escudé, por seu turno, é responsável pela formação de professores para o ensino de línguas no programa bilíngue occitano-francês do Ministério da Educação da França.

O objetivo da obra em questão é oferecer um exame preciso - e de fácil leitura - das pesquisas e dos conteúdos pedagógicos produzidos no arcabouço teórico da intercompreensão, a partir de seus principais referenciais. A intercompreensão é, a propósito, uma das quatro

$\triangle$ tomhynde@gmail.com 


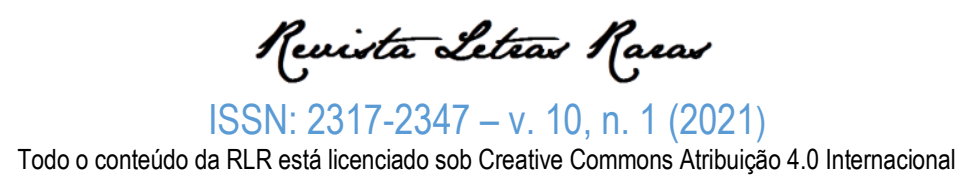

abordagens plurais que propiciam a criação de uma consciência plurilíngue, na comunicação, priorizando a interação social. Através dela, cada interlocutor fala ou escreve em sua língua materna (ou em outra língua estrangeira com a qual ele se sinta confortável), um tentando compreender a língua do outro.

Ao adentrar na matéria, os autores deixam claro que a abordagem da intercompreensão não almeja suceder metodologias consolidadas previamente; visa, antes, a atuar como um complemento a estas, desde que certas estratégias sejam seguidas, desmistificando a ideia de que misturar línguas seja uma prática reprovável na área de linguística aplicada e de ensino de línguas estrangeiras.

Neste sentido, Olmo e Escudé apresentam os meandros e as nuances da intercompreensão, investigando os pilares teóricos que a amparam, além de analisar as transformações que a intercompreensão suscita no âmbito do ensino de línguas, bem como na constituição linguística dos indivíduos. São expostas, também, reflexões sobre os modos de elaboração de didáticas intercompreensivas. Vale ressaltar, ainda, que o livro procura responder quais são os elementos facilitadores e aqueles que criam obstáculos aos falantes de português brasileiro em relação às demais línguas românicas.

No tocante à organização da obra, esta é composta por cinco capítulos, além do apêndice e um anexo. Ao primeiro capítulo foi atribuído o título de Representações da linguagem e das línguas. Neste, os autores tratam da variação e dos universais linguísticos. Para isso, recorrem ao Curso de linguística geral do professor suíço, Ferdinand de Saussure, a fim de percorrer por noções como as de signo linguístico.

Deste modo, Olmo e Escudé chamam a atenção para o fato de que os ruídos (ou interferências) que atrapalham a transmissão da mensagem emanada - pelo emissor ao receptor - são causados não apenas pelas distâncias geográficas e temporais, mas também pela distância cultural, já que, por exemplo, no caso de um francófono oriundo do Quebec, "provavelmente a palavra arbre crie a imagem de alguma árvore genérica do bosque boreal (...); já para um francófono do Caribe (...) a mesma palavra, arbre, estará associada primeiramente a espécies tropicais presente no seu contexto geográfico" (p. 15).

Tendo isso em vista, um ponto importante abordado, no livro, a partir das teorias de Saussure, é a ação de duas forças que agem concomitantemente: o espírito campanário (ou paroquialismo) e a força do intercurso. Isso porque há um vívido contraste - numa mesma sociedade (nem sempre num mesmo indivíduo) - entre o desejo centrípeto (identitário) e o desejo 


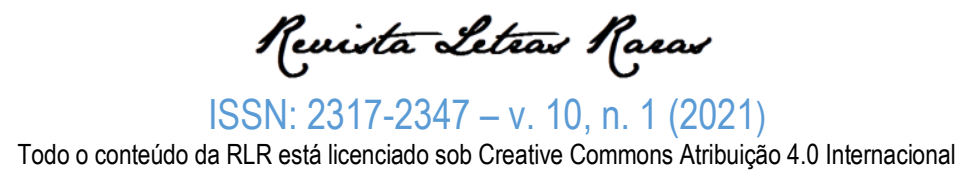

centrífugo, que impulsiona o indivíduo a lançar-se em lugares e culturas outros. Assim, o espírito campanário põe em relevo qualquer nova expressão do lugar, a fim de torná-la - o mais rápido possível - típica, tradicional. A força do intercurso, por sua vez, "reúne todos os fenômenos que promovem intercâmbios entre as comunidades mais ou menos próximas e se posiciona no rumo da fusão, da identificação mútua" (p. 16).

Na sequência, os autores trazem a arte para ilustrar a teoria, uma vez que utilizam, metaforicamente, obras da literatura, como o conto Storia di Tönle, produzido por Mario Rigoni Stern, escritor italiano, e Baudolino, romance escrito pelo também italiano, Umberto Eco. Além disso, recorrem ao cinema e fazem uma síntese de L'enfant sauvage, do diretor francês François Truffaut, que conta a história de Victor, um garoto que sobreviveu entre animais, sem a presença de humanos. Tudo isso com o estratégico intuito de pôr em ação as primeiras noções introduzidas até aqui, o que nos parece bastante pertinente, porquanto essas exemplificações auxiliam o leitor a assimilar de forma mais eficaz os conceitos anteriormente tratados.

Em seguida, são discutidos os aspectos psicológicos, sociais e políticos do plurilinguismo. Ao darem destaque ao fato de que todos nascemos plurilíngues, Olmo e Escudé explicam que o monolinguismo que atinge a grande maioria dos cidadãos provém de imposições das estruturas do poder estatal. Isto é, a linguagem é inata, mas os princípios sociopolíticos ostentados pelas escolas são decisivos para a expansão (ou não) das competências linguísticas dos indivíduos.

No decorrer deste primeiro capítulo, essencial para o entendimento de todo o conteúdo subsequente, os pesquisadores vagam por questões que tratam da intercompreensão como alternativa ética, trazendo os cenários da comunicação exolíngue, bem como as origens do vocábulo "intercompreensão", culminando com a presença e a simbologia da diversidade linguística nas abordagens mitológicas.

Já no segundo capítulo, os autores versam, mormente, sobre os conceitos operacionais da didática da intercompreensão. Um deles é a noção de continuum linguístico, "um dos pilares epistemológicos da intercompreensão" (p. 51), o qual se baseia na proximidade entre línguas de uma mesma família, produzindo zonas de transparência entre elas, como é o caso das línguas da família românica (o português, o espanhol, o francês, o italiano, o romeno etc).

Na página 55, Olmo e Escudé suscitam, outrossim, um exemplo interessante para explicar a noção de continuum linguístico e demonstrar a intercompreensão na prática, chamando os leitores a imaginar um mochileiro chileno que parte em viagem pelo continente latino-americano. Isso porque este viajante teria que se comunicar, ao longo do caminho, com diferentes variedades 


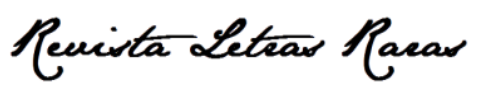

ISSN: 2317-2347 - V. 10, n. 1 (2021)

Todo o conteúdo da RLR está licenciado sob Creative Commons Atribuição 4.0 Internacional

da língua espanhola. Certo de que as línguas de seus vizinhos de continente apresentam porosidade o bastante, a fim de possibilitar uma comunicação fluida com variedades mais ou menos distantes do espanhol, o mochileiro precisaria, no entanto, "negociar os significados, reformular determinada frase ou expressão se perceber uma falha ou um mal-entendido na comunicação" (p. 55). Ocorreria o mesmo, aliás, se decidisse atravessar o Brasil, explorando as zonas de transparência entre as línguas espanhola e portuguesa. Não obstante a clareza da ideia exposta, ela ficou mais como uma sugestão daquilo que poderia ocorrer nesta viagem fictícia; por isso, acreditamos que teria sido profícuo desenvolvê-la e aprofundá-la, a fim de expor aos leitores a intercompreensão em funcionamento.

Outro conceito operacional abordado, no segundo capítulo, é a intencionalidade, que depende do comportamento dos interlocutores e sua capacidade em negociar, isto é, deve haver boa vontade entre as partes, a fim de que a mensagem seja passada de forma clara. E o terceiro conceito operacional da didática da intercompreensão analisado é a previsibilidade, que é dada pelo contexto e pela forma, tendo como suporte a ideia de transferência de competências e conhecimentos prévios (linguísticos ou não).

Além destes conceitos, os autores analisam, no mesmo capítulo, as estratégias de intercompreensão, como a estratégia de transferência, "definida como o conjunto de processos cognitivos através dos quais a realização de uma atividade numa situação dada será facilitada pelo domínio de uma atividade similar previamente adquirida" (p. 63), e a estratégia de aproximação, "definida como o conjunto de aproximações sucessivas para inferir o conteúdo e a forma" (p. 64).

O terceiro capítulo da obra, por sua vez, tem como título: "O acervo lexical das línguas românicas aplicado à intercompreensão". Nele, Olmo e Escudé tratam da diversidade entre as línguas humanas e destacam a importância em se construir pontes entre elas, a fim de acessar outras línguas do mesmo continuum (no caso do livro em questão, o foco é a família românica). Deste modo, a intercompreensão dá ensejo ao desenvolvimento de uma maior capacidade metalinguística na compreensão do todo, ampliando a visão holística dos interlocutores quanto ao modus operandi de diferentes sistemas linguísticos.

$\mathrm{Na}$ continuação, adentra-se no acervo lexical românico, perpassando por temas relevantes, como por exemplo: os empréstimos intrarromânicos, assim como aqueles procedentes de outras línguas; os prefixos e os sufixos; os "falsos" amigos, os quais nos são revelados como os melhores amigos da intercompreensão; e as zonas de opacidade e de transparência, ou seja, 


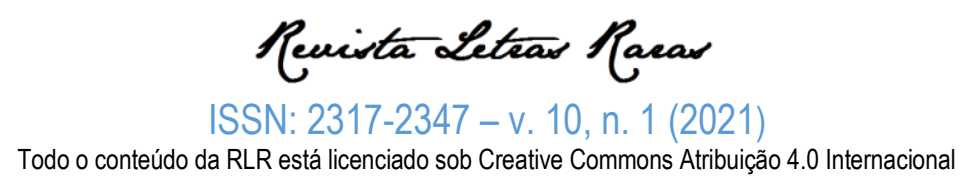

aquelas que apresentam elementos de dispersão e de convergência, respectivamente. Assim, "reconhecemos as palavras transparentes tanto pela forma quanto pelo conteúdo: por exemplo, pt. es. cat. política, oc. it. politica, fr. politique, ro. politică" (p. 106).

"Pontes e alavancas morfológicas no desenvolvimento de competências metalinguísticas" é o título dado ao capítulo seguinte, no qual são abordados tópicos que discorrem sobre analogias e contrastes entre as línguas do continuum linguístico românico: flexão nominal; gênero gramatical; formação do plural; artigos definidos e indefinidos; verbo; negação; preposição, entre outros elementos que aproximam e distanciam as línguas do continuum. São feitos, então, comentários comparativos, com bastante objetividade, a fim de apontar "as semelhanças e os contrastes de uma série de fenômenos compartilhados - alavancas facilitadoras da intercompreensão" (p. 111).

Ainda no quarto capítulo, os autores traçam os perfis de cada língua da família românica, do galego-português ao romeno, sendo esta última - dentro do continuum românico - a mais distante do português, isto é, a que apresenta um maior número de zonas de opacidade e poucas zonas de transparência. Diferentemente, para um lusófono, as línguas espanhola e italiana parecem bem mais próximas. Aprendemos, também, que a língua francesa ostenta uma grande opacidade para muitos falantes de outras línguas românicas, inclusive a portuguesa, visto que 0 francês é a mais germânica entre as línguas românicas e possui um complexo sistema vocálico.

Chegando ao quinto e último capítulo da obra, deparamo-nos com o título: "Projetos e materiais didáticos". Essa é, ao nosso ver, uma parte fundamental da obra, porque expõe os métodos com os quais a teoria, até então tratada, é posta em prática. A propósito, a maior parte dos materiais apresentados, neste capítulo, são encontrados na internet de forma gratuita. Há uma primeira seção que abrange os "métodos pedagógicos de intercompreensão baseados no ensinoaprendizagem de habilidades receptivas, (...) assim, o falante de uma língua românica aprenderá a ler em outras línguas pertencentes à mesma família" (p. 155). Em outra seção do capítulo, Olmo e Escudé ocupam-se do enfoque interacionista da didática da intercompreensão, com recursos online: "seu objetivo se aproxima dos trabalhos precedentes, pois também propõem estratégias para a leitura plurilíngue, acrescentando a interação entre os participantes" (p. 160).

Por outro lado, os métodos postos em evidência, até esse momento da obra, são indicados aos adultos. Por isso, os autores dedicam-se, na sessão subsequente, a apresentar métodos voltados ao público infantil. Métodos estes que servem como um despertar para as línguas, isto é, objetivam estimular a sensibilidade do público infantil para a diversidade cultural e linguística. 


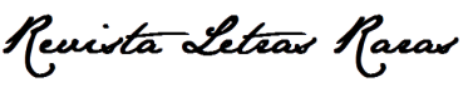

ISSN: 2317-2347 - V. 10, n. 1 (2021)

Todo o conteúdo da RLR está licenciado sob Creative Commons Atribuição 4.0 Internacional

Ademais, o presente capítulo ainda toca em assuntos complexos, como a viabilidade e os obstáculos para a integração curricular da intercompreensão: "as qualidades que fundamentam a originalidade e a efetividade da intercompreensão para reformular os paradigmas existentes podem-se tornar um pretexto para rejeitá-la se forem mal interpretadas pela comunidade educativa ou pelos atores políticos" (p. 177). Além dos cinco capítulos apresentados, a obra ainda abarca, no apêndice, uma variedade de propostas didáticas, as quais podem ser utilizadas na formulação de materiais didáticos em intercompreensão. Ao final, no anexo da obra, encontra-se um exemplo de formulário avaliativo de formação, o qual deve ser respondido pelos participantes das aulas de intercompreensão.

Destacamos, ainda, a exitosa empreitada dos autores ao demonstrar e ao explorar os elementos facilitadores, os quais são chamados por eles de "pontes e alavancas", da comunicação entre o falante do português brasileiro e o falante de outras línguas do continuum românico, bem como aqueles elementos que obstaculizam a comunicação. Vemos, a partir disso, que a intercompreensão não se trata de expandir um acervo de palavras, mas de um levantamento do sentido geral, com o auxílio de inferências de significados e de interações. Por outro lado, certas características marcam um distanciamento no continuum, como é o caso da formação do plural ou mesmo de sistemas vocálicos complexos (a língua francesa é um bom exemplo).

Por fim, ressaltamos a importância da obra em análise e indicamos sua leitura, porquanto introduz e discute um tema relevante para os apreciadores da linguagem e para os professores que vivenciam questões que abarcam a didática e o ensino de línguas estrangeiras. Aos pesquisadores e pós-graduandos em Letras ou áreas afins, a leitura desta obra propicia a apreensão de diversos conceitos relativos ao plurilinguismo e às abordagens plurais, sobretudo à intercompreensão. Logo, acreditamos que a obra de Olmo e Escudé viabiliza, ao leitor, o contato com um tema até então pouco explorado, uma vez que a intercompreensão é uma didática subversiva que ainda encontra muita resistência, embora haja cada vez mais professores/pesquisadores interessados pela intercompreensão, a qual vem mobilizando debates em eventos científicos voltados a ela. 